\title{
THE INFLUENCE OF MORTGAGE LENDERS ON BUILDING DESIGN
}

\author{
JOHN B. HALPER*
}

I

\section{What Design and Where?}

Driving through a typical American city several years ago, a bank officer and I were visibly depressed by the uniformity and mediocrity of design, as well as the complete void of aesthetic quality in a better than average tract of middle-income homes. Despite the apparent middle-class virtues of shrubbery and lawn maintenance, the appearance of the structures was so appallingly drab that the banker remarked: "Since it seems just as easy to design a good building as a poor one, I always wonder why they don't put a little craftsmanship in them anymore."

I have thought about this observation many times since then, and have reached two basic conclusions: (I) it is easier to design and build the "drabs" only because repetition of the approved formula is both what the building trade feels safe with and what the lenders will knowingly lend against; and (2) since lenders do not insist upon "quality control," much less aesthetic appearance, there is little reason to donate extra effort to the buying public. Quality control is distinct from adherence to specifications, which do not relate to quality in the first place; they merely insure that the building is adequate to endure the life of the mortgage.

A corollary of this is the outright fear many builders have of being original, daring, and producing something for which there is no set lending pattern, that is, no proven yardstick to establish the all important loan-to-value ratio. While these drawbacks in design are largely attributable to timorous lending practices, they have a pervasive effect on borrowers, so that the cycle goes full circle.

A case in point was "The Willows," an attractive type of bee-hive design complex of doctors' offices and labs in Westport, Connecticut. Breaking away from the rectangle or hollow-square design, the architect sought to produce not only a more functional building, but a series of interlocking, or bee-hive, offices with ample and accessible parking space, creating an idea that would fit aesthetically into both landscape and the quasi-rustic locale. Despite the long leases of the doctor-tenants, no insurance company would advance the mortgage funds. Reason: simply no prior experience with such an odd-ball design, no way to compute cubic feet by accepted slide-rule practice, thus no way to measure up the loan.

* B.A. 1946, M.A. 1947, Columbia University; Diploma 1949, Ecole de Hatte Finance, University of Geneva. President, Halper \& Co., Inc., a firm engaged in private mortgage and investment banking and brokerage, headquartered in New York. Mr. Halper served as a correspondent in Switzerland for Business Week and other McGraw-Hill publications; in Washington, D.C., for Congressional Quarterly; and in New York for Value Line Investment Survey, before establishing his own firm in 1964 . 
The problem was finally settled, if not solved, by bringing in a more flexible New York bank which was sufficiently impressed with the appearance and the endorsement of the tenants to issue the loan, but not at the full amount requested because of the higher "risk" involved in unique construction and design. Needless to say, the next group of doctors desiring to build an office complex turned to a more conventional mold and received a higher loan for their prudence.

While this might demonstrate the force of lenders on design, it is not to imply that all lenders exert a negative influence-merely one heavily coated with conservatism. With regard to shopping centers and major-tenant office buildings, where the national credit rating of the tenant virtually serves as "insurance" for the loan, the most advanced designs in the United States (though not North America) may be seen. ${ }^{1}$ But in the field of housing - whether single-family or apartments, Federal Housing Administration (FHA) or conventional-the kindest compliment that can be credited to a lender's influence on the aesthetic continuum is sheer disinterest. That is, he does not actually insist upon square shapes.

Many of the problems arising from this negative influence may be traced directly to FHA codes which, in turn, have produced what is commonly called in the trade either "FHA modern" or "late VA" styles. The blame can be laid squarely on the agency's desire for standardized procedures which allow it to insure mortgages at the lowest common denominator of design and building technique.

For example, the difference between cheap and very good residential construction ranges between $\$ \mathrm{r} .25$ and $\$ \mathrm{r} .50$ in cost, approximately a twenty per cent gap. But mortgage lenders make only minor distinctions between good and poor construction. Money is lent on an estimated rent roll; and a cheap speculative building will produce a rent roll very near that of a high quality structure. Tenants, one might assume, will not renew their leases in a shoddy building, but by that time most speculative builders will have taken their accelerated depreciation and sold out for a capital gain. A graphic demonstration of the effect of different cubic foot construction costs for a high-rise in Charlotte, North Carolina, which has $x, 000,000$ cubic feet (rounded off), is shown in table I.

Funds received by the builder through the mortgage are the same for all practical purposes in these three cases. Yet the difference between very cheap and good is $\$ 250,000$. In other words, every cent per cubic foot saved by cost cutting on the quality of construction is a savings of $\$$ I 0,000 for the builder. Thus, in our example, the cost increase between poor quality and good is 18.5 per cent, while the difference between reasonable quality and good is less than seven per cent. Since lenders do not reduce their loans for poorer quality construction by the same percentage ratio as the savings to builders, they indirectly encourage the cheaper construction.

\footnotetext{
${ }^{1}$ Mexico and Brazil are years ahead of the United States in this respect.
} 
TABLE $x$

Comparative Construction Costs

\begin{tabular}{l|c|c|c}
\hline $\begin{array}{c}\text { Construction } \\
\text { Quality }\end{array}$ & Land Cost & $\begin{array}{c}\text { Construction } \\
\text { Cost }\end{array}$ & Total \\
\hline $\begin{array}{l}\text { Cheap- } \\
\$ 1.25\end{array}$ & $\$ 100,000$ & $\$ 1,250,000$ & $\$ 1,350,000$ \\
\hline $\begin{array}{l}\text { Reasonable- } \\
\$ 1.40\end{array}$ & $\$ 100,000$ & $\$ 1,400,000$ & $\$ 1,500,000$ \\
\hline $\begin{array}{l}\text { Good- } \\
\$ 1.50\end{array}$ & $\$ 100,000$ & $\$ 1,500,000$ & $\$ 1,600,000$ \\
\hline
\end{tabular}

In reviewing the role that lending institutions have exerted on building quality, even by default, it would appear at times that they have all but abdicated their influence. Yet that power of influence is maintained as a vast potential, and can be heavily leveraged when mortgage funds are needed and money is tight.

While some helpful hints or suggestions might be made to the prospective borrower during, or after, an inspection of the property site-and when it is often too late to alter architectural design-few aesthetic demands are imposed as a condition precedent to the loan.

In going back through years of requirements on file, I find copious inter-office memoranda from senior fund officials instructing their loan officers or appraisers to double check on zoning, easements, and deed restrictions; off-site requirements, such as utilities, wells, or gas mains; plottage, embankments, and drainage; and even such matters as proximity to odors, smoke, or unusual noise. But seldom is seen a strict pronounciamento to advance or withhold funds because of design or architectural merit, even using such tests as conformity to terrain or use of the building. This critique applies equally to FHA or conventional dwellings, single or multiple. It does not apply to office buildings where, as was pointed out earlier, occupancy by rated tenants permits more advanced, and even highly advanced, design.

Once a loan is committed and the structure is up, the prime interest of both sponsor and lender is merged into one question-will it sell, or rent? All other requirements, or gimmicks, are irrelevant if the result remains empty.

To avoid this catastrophe, sales glamor can often overcome what shoddy, slab construction or poor design imposes. This is especially true if the glamor shows in the right places, such as the building lobby, elevators, kitchens, or terraces. Largely due to the glamor concept, interior decorators have been elevated to new status, while architects have been downgraded. In fact, draftsmen will do, as long as the lending 
institution has the report of a "supervising architect" to enforce the specifications and codes.

In a high-rise apartment the lobby (or entrance foyers in a garden-type apartment) is the first spot greeting the tenant; and while styles change, the lobby is always in keeping with the current middle-class taste. This calls for an ample thickness of foam in the carpenting, textured or scenic wall paper, and a sufficiency of bronzelacquer in the chandeliers.

The next eye-catcher is the elevator bank. Self-operated elevators are a must due to prohibitive labor costs (except in very expensive apartments). Regardless of the decor, the elevators are starkly modern because people, as well as lenders, look for the ultra-modern in machinery, despite any clash in decorating styles.

Kitchens are another glamor feature because they make a good selling point, even if they are out of proportion to the rest of the interior composition. Over-sized refrigerators and stoves, relatively speaking, even when there is no separation between kitchen and living room, catch the eye and keep it from wandering elsewhere.

The competitive market, moreover, has created another idiocy-namely the apartment terrace. This is oftentimes little more than a narrow catwalk which more frequently provides neither sunlight nor view, except over a highway or flapping laundry. The concrete shelf is rarely used by the tenant and serves as a thin status symbol. The FHA codes are almost wholly responsible for the balcony disease. The agency has defined a balcony as a room, thus including it in the room count on which funds are allocated. Since balconies cost approximately $\$ 85^{\circ}$ to $\$ \mathrm{r}, 000$ each, but get an allowance twice that much, builders often thin their equity and install balconies for a higher loan. No wonder FHA projects in northern Alaska have sprouted balconies. Conventional buildings, while not receiving the same monetary blessing, are forced by sheer competition to go along.

We have said relatively little thus far about lenders' influence on single-family homes, and, for that matter, there has been little influence. There are, indeed, definite requirements as to the minimum square feet or number of bathrooms in a fixed-price-range house, but we find a paucity of comment as to design.

A uniquely architected home, for example, in contemporary styling with an abundance of glass panels, open fireplaces, and expanse of redwood deck is not favored by lending institutions just because it may have won a design award or enhances the area. It is more often looked upon as an expression of an individual's idiosyncrasy, on which they are reluctant to advance funds because they are concerned about its resale potential in a stock home market. Thus, penalizing it with a fifty to sixty per cent loan instead of a seventy-five to eighty per cent loan to value (which is the same as cost in this instance), they are exerting the negative influence of keeping imaginative design within bounds. It appears that only the wealthy or the bold, or both, may transgress those bounds. 
II

\section{Lenders' CrIteria}

Some of the larger institutions, such as Equitable Assurance, Mutual Benefit, and Prudential Life Insurance, do indeed make a contributory effort toward the encouragement of good design and quality construction through rigorous adherence to tougher specifications. But since they cannot arbitrarily reject all "poorly designed" residential buildings and remain competitive, they have, by and large, exerted a positive influence by giving preference to well designed structures.

This is particularly applicable to large, expensive edifices where the smaller lenders, such as the local Savings and Loan associations, are forced to withdraw from competitive bidding. In California, for example, where building activity has been intense as well as hectic for two decades, an experienced observer will note that the better-designed, high-unit-cost apartments are almost exclusively backed by top-notch lenders. The reason for this is based on three factors, in order of importance: (I) prestige, which rubs off on the lender; (2) safety of investment in knowing that good design will command occupancy for the life of the loan; and (3) default of competition in the field.

I think this demonstrates, rather than proves, that where there is an election as to which loan to make, the loan will be given to the advanced, though not radical, design. The trouble is that there is frequently no choice to make, since most designs are poor to begin with because there is no insistence upon or premium for them.

Lenders are fully cognizant that an expensive, well-designed, high-unit-cost dwelling creates a more insured long-range security. Against this realization, however, are weighted the business-like exigencies of putting out the least loan amount for the highest return in keeping with the market, as well as the ever present concern about recovery in event of foreclosure. Unfortunately, it is usually the latter consideration which outweighs the former when the decision is close.

\section{III}

\section{BORROWERS' REACTIONS}

Few things are more sensitive than a borrower seeking money. Sensing that lenders base their outlays on two factors-income from the project and current replacement costs in the area-the borrower has responded to the challenge in a manner to be expected rather than admired. He has jacked up rentals to what he feels the traffic can bear, while reducing maintenance to what the lenders, or tenants, will allow; and he has inflated his construction or land costs so as to arrive at the highest value assignable to his project in order to offset the lender's paring.

While this has been reduced to a mathematical game for both sides, few bonuses are granted the builder who goes out of his way to create something of great merit or which reflects advanced design. Why should he, he reasons, since the real com- 
pensation lies elsewhere, and he is rarely in the business for aesthetic satisfaction. Ironically, even to slip into a good design which might cost more is to impose a financial penalty upon himself, because the lender offers no premium.

\section{IV}

\section{What Mrght Be Done}

Earlier in this article I referred to the banker who thought well-designed homes might actually cost, size for size, no more than badly designed homes. While this might be true in theory, it cannot be true in today's practice simply because almost all existing patterns, once approved in lending circles, are endlessly and cheaply reproduced. Therefore, a builder, desirous of a larger loan, knows that for every $\$$ I.00 spent on space or glamor, he can gain approximately $\$ r .30$ in loan value, up to certain limits, of course.

I am sure that the smallish, compact houses built in colonial Williamsburg over two hundred years ago were not only carefully constructed and aesthetically designed by home-grown architects of its day, but that the construction was as inexpensive as a prudent and cash-poor squirearchy could afford. Yet, there is a lasting, good form inherent in the original style, layout, and design which no Levittown has matched. In other words, there was an example of good design of enduring beauty, as inexpensive in its era as some of the future slums we are building today along arterial highways in our expanding "strip" towns.

Since we may conclude that builders will not voluntarily elect to improve residential design-because innovations often work against them-it is left to the major lending institutions to insist upon and reward aesthetically-pleasing residential structures. Imagination and innovation could be encouraged, in fact, by the one thing builders readily understand: monetary inducements.

Each loan application, when it goes before the approving committee, could be granted a premium should the project show design merit over and above its basic loan requirements. So many dollars, or so many percentage points of additional loan, could easily be granted for, say, intricate landscaping, brick lattice work, gas-lit townhouses, arched or recessed doorways, homes staggered on the lots, and all the myriad ideas that could affect the result.

In setting up such a practice, lenders would not only help beautify America and improve the dismal appearance of the high-density sectors of the cities, but also would perform a service to their own self-interest. They would not only forestall future slums, too many of which are now aborning, but also would help insure continued occupany at stabilized rentals. In turn, this would save the time and expense of foreclosure and forced sale, although that happening is usually remote.

In the few instances where this approach has been taken, such as in Reston, Virginia, it was Gulf Oil Company, rather than a usual lender, that was ready, 
willing, and able to take the first step. Having proven that good design and land planning is both feasible and fiscally sound, it is also smart business. ${ }^{2}$

It is also one of the major steps that should be undertaken in the private sector of the economy because the government, primarily preoccupied with mass housing as shelter, cannot initiate such a "frill" for fear of criticism. Enlightened self-interest, however, cannot neglect it for long.

\section{V}

\section{Private Investment in Slum Improvement}

In early Ig66 I made the suggestion to Robert C. Wood, Undersecretary of the Department of Housing and Urban Development, that little would be accomplished in slum and ghetto rehabilitation unless some means were agreed upon to induce a massive infusion of private insurance company funds as part of a concerted effort to get the program under way meaningfully. ${ }^{3}$ For, in the United States, government programs frequently flounder, even after surviving protracted and crippling legislation, unless they are enthusiastically backed by large segments of private industry and capital. And what is more realistic support than monetary commitments to back slum redevelopment at normal, rather than high risk, rates.

The suggestion carried the point that a consortium of major insurance companies, brought together by the Department and apprised of the magnitude of the problem, would be able to confront the task pragmatically-provided they were given a form of government-backed, FHA-type of loan insurance to offset the added risk.

Insofar as there are almost $35^{\circ}$ life insurance companies in the United States, all of whom are capable of making some form of long-term commitments to improve real estate at a reasonable return, perhaps a third of that number could be interested in participating in such a program. If so, that alone would constitute a major breakthrough in steering private capital into ghetto housing. With well over \$15 million being channeled from these sources alone into real estate annually, surely it would not be too much to ask that a small portion be syphoned off toward improving the quality of life in the cities.

There is a further suggestion that an insurance industry committee be formed to promote the overall project by recruiting builders who meet tests of adequacy as well as would-be sponsors of low-cost housing. Landholders, agreeing to sell land at less than unconscionable prices, should also be induced to cooperate.

While in practice each participating company would direct its own investments, this would become an excellent opportunity to insist upon good design as an integral

\footnotetext{
${ }^{2}$ Reston has received an infusion of funds because of the vastness of the undertaking.

${ }^{3}$ It has recently been announced that this program, as proposed, has been adopted in principle by the major insurance companies as of September 14,1967 . Insurance lenders, perhaps $98 \%$ being life companies, make larger and longer term investments than banks, by and large. Long-term bank commitments come mainly from their pension trusts for which they act as fiduciary trustee, and not for their own account.
} 
part of the loan package. Indeed, it should be a condition precedent to granting the loan, provided there are enough sponsors bidding for the work project.

In fact, my original suggestion to the Department points out that special attention be directed to the creation of "townhouse" type of construction, designed to fit the heavy density pattern of the intra-urban area. Townhouses, as distinct from row houses, can be one of the most aesthetically pleasing architectural forms adaptable for metropolitan environment. ${ }^{4}$

Aside from the excellent townhouse grouping in Southwest Washington, D.C. (recently completed), a historical example may be observed in London as "redeveloped" after the great fire of 1667 . Many of its present townhouses were the result of early slum improvement following the fire, and although most of them were replaced during the nineteenth century, the architectural concept remains-along with gardens and trees and walkways built into the center of the square surrounded by relatively low-cost, compact houses, each slightly different but well designed and fitting pleasingly into their "urbascape." In fact, Samuel Pepys tells us that much of the rebuilding effort was directed by the city's insurance underwriters who, in an attempt to reduce their insurance risks, demanded better construction and congestion control. Hence, many of the open squares and crescents, which only later became parks or community gardens.

The same concept, stimulated not by fire this time but by the seething misery of poverty and eruptive violence, should be implemented. But the major theme of this article is that redevelopment without specific attention to well-oriented design of both the dwelling and its surrounding would be nothing more than the heedless creation of future slums within an immediate Kafkaesque nightmare.

If such a program of redevelopment becomes a reality through the auspices of the Department of Housing and Urban Development, and if insurance company lenders do not insist upon and reward aesthetic contributions to design, then both sides will have recommitted so grievous an error as to be downright shameful.

People who work in cities should have a chance not only to live there but also simply to enjoy their homes and surroundings as part of a lasting solution.

'This was also a part of the suggestion which the writer made to the Department of Housing and Urban Development, Feb. 16 , r966. 